\title{
通勤者における消費時間弁別閾の確率的評価

\author{
STOCHASTIC EVALUATION OF COMMUTER'S DISCRIMINATION \\ THRESHOLD FOR TIME CONSUMPTION
}

\author{
家田 仁*・後藤貞二**・松本嘉司***・島崎敏 一**** \\ By Hitoshi IEDA, Teiji GOTO, Yoshiji MATSUMOTO and Toshikazu SHIMAZAKI
}

\begin{abstract}
Time consumption is known to make great influence on passenger's transportation choice behaviour. But it is assumed that travelers recognize time consumption continually in contemporary used many behavioural models. Actually the difference of time consumption smaller than some critical value should not be recognized as virtual difference in comparing characteristics of plural transportation devices or evaluation of some project about reduction of time consumption. In this study, discrimination threshold of time consumption (DTT) is proposed for traveler's recognition of time consumption, and commuter's access behaviour to railway station is expressed mathematically as their decision making behaviour of scheduled arrival time to estimate their stochastic distribution of DTT
\end{abstract}

Keywords : discrimination threshold, time consumption

\section{1. まえがき}

交通手段などの選択行動には，時間・費用などの各種 の因子が影響を及ぼしているが，その中でも時間的要素 は最も重要なものの 1 つである. 実際, 中長距離輸送で 航空機, 自動車とのし烈な競争を繰り広げている鉄道旅 客輸送においても, 最近の列車ダイヤの改正では, 拠点 都市間の所要時間短縮による輸送シェアの確保・増大を 目的として, 特急旅客列車を中心とする列車速度向上施 策が積極的に推進されている.しかしながら,こうした 列車速度向上施策は, 新幹線などの新線開業, 塩嶺卜ン ネルのような短絡ルートなどを除き，現存する軌道およ び車両などに改良投資を施すことによるものが多く，少 なからぬ投資が必要とされる割には, 短縮時間は数分か ら十数分程度のものが多くを占めている．このような施 策が旅客誘引効果や宣伝効果など有効な営業効果をもた らすためには, 短縮された時間差が少なくも利用者に意

* 正会員 工博 東京大学助教授 工学部土木工学科 ( ₹113 文京区本郷 7-3-1)

** 正会員 工修 和歌山県土木部 ( ₹640 和歌山市小松原通 1-1)

*** 正会員 工博 東京大学教授 工学部土木工学科 ( ₹113 文京区本郷 7-3-1)

**** 正会員 工博 東京大学助教授 工学部土木工学科 (同上)
味のある時間差として認識され，新たな交通行動の判断 を行わしむるものであることが必要である．こうした意 味で利用者の時間差に対する認識の限度を知ることは実 務上重要な課題である．また，都市圈の鉄道輸送におい ても列車の運行間隔を短縮しサービスを向上することに より旅客の確保を図る, いわゆるフリークェントサービ ス化が進められているが利用者の心理的特性からみてど の程度の列車運行間隔が “フリークェント”とみなされ るのかを探った研究は見当たらない.

本研究は，このような問題意識のもとに消費時間がど の程度の差をもったときにそれが利用者にとって有効な 差であると認識されるのかを把握するため, 計量心理学 でいう弁別闌 (Discrimination Threshold) の概念を導 入し, 利用者集団における消費時間の弁別閾の分布, す なわち利用者の時間差認知の最小単位の集団内分布を鉄 道駅における通勤者のアクセス行動を対象とする実測調 查に基づいて推定することを試みたものである.

\section{2. 従来の研究と本研究の特長}

計量心理学でいう弁別閾とは識別可能な 2 つの刺激の 大きさの差の最小值で, ちょうど可知差異 (jnd : just noticeable difference) ともよばれる. 種々の刺激に対 する弁別閾は, 研究対象となる母集団からランダムに選 
ばれた被験者に対して実験の環境を統制したうえで，極 限法, 平均偏差法 (調整法), 反応時間法 (潜時法), 恒 常刺激法なよ゙の方法により測定されるのが普通である が1)，こうした弁別閥には個体差，場合差のような変動

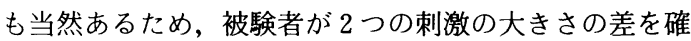
認できる確率が $50 \%$ であるときの刺激差を求め, これ を弁別閾とされることが多い2 ${ }^{21}$. 従来, 研究対象とされ た感覚様相としては視覚, 聴覚, 味覚, 臭覚, 触覚, 重 量感覚などのいわゆる「五感」にかかわるものが中心で, 重要な物理的次元の 1 つである時間については十分な成 果が得られているとはいいがたい状況にある.これは， 時間が他の感覚様相と異なり，人間がそれに対する特定 の受容器をもたないことなどがその理由に挙げられてい る ${ }^{2)}$. 人間の時間認識の方法としては 2 つが挙げられて いる. 1 つは発現時点の異なる 2 つの事象に挟まれた時 間間隔（空虚時程）をこの $2 つ の$ 事象の認知を通じて認 識するとするもので，もう 1 つはある刺激が継続して与 えられている時間 (充実時程) をその刺激の連続的な認 知から認識するとするものである ${ }^{3)}$.このように，時間 を知覚の対象として取り扱うには他の感覚様相にはない 特殊性を伴っている.

交通計画において時間不効用の判断限界を求めた研究 の一例として, 谷・宮武の研究 ${ }^{4)}$ があるが, これは通勤 手段の選択モデルの定式化にあたって 2 経路の効用差の 評価値が小さい值の場合，利用者は確定的な選択ができ なくなると考え, 比較判断の閥值 (判断限界) をモデル に組み込みこの值を他の因子（着席乗車時間，立席乗車 時間，乗り換え回数，運転間隔，歩行時間，等）の重み とともに推定したものである.これによると東京の通勤 者では着席乗車時間 1 分間の与える不効用を 1 としたと き運転間隔 1 分間の不効用は 1.028 であり, 不効用の判 断限界は 2.410 と推定されている. したがって, 判断限 界は運転間隔いわば待ち時間に対して 2 分程度 (2.410 $\div 1.028=2.344)$ となっている.ただし，この研究は一 対比較形式の仮想的状況を呈示して回答を求める, いわ ゆる意識調査によるものであり，また判断の閾値を集団 の中で確定的な 1 つの数値として推定しており，その個 人差によるばらつきは考慮されていない.

前述のように計量心理学における精神物理学的測定法 では, 実験室内で被験者に刺激を与え，その反応を観察 するまたは自覚的反応を聴取することにより把握するの が普通であるが，このような実験室内での実験でも教示 による反応統制のあり方，被験者の観察反応といったよ うな問題もあるし ${ }^{5)}$ ，また時間感覚が前述のように他の 感覚様相とは異なる特殊な性質をもつものであること や，また本研究で対象とする時間が交通環境における人 間行動を捉えるうえでの特有の意味をもった “時間”で
あることから，ここでは利用者の実際の交通行動を通し て利用者の時間認識の特性を把握することとした.なお, 利用者の行動を利用者それぞれからの聴取により調査す る方法は, 非集計行動モデルを用いた分析などで行われ ているが，こうした方法による場合，利用者の記憶に依 存することから聴取結果があいまいであるとか時間につ いては 5 分や 10 分単位の回答が多いというような問題 点 $^{6)}$ もあり, 本研究で扱う時間弁別閾のような微妙な時 間概念を対象とする場合には必ずしも適切とは考え難 い.そこで本研究では被験者に実験を意識させない方法, いいかえれば被験者の実際の行動を外的に観測する方法 によってデー夕収集を行った.この方法による場合, デー 夕の収集項目数や収集量に限界はあるが，客観的なデー 夕を得るという点では意義をもつものといえる.

\section{3. 消費時間弁別闘を考慮した通勤者の鉄道駅 へのアクセス行動の定式化}

利用者の時間弁別閾の問題を捉えるには，単純に考え るならば所要時間の異なる複数の交通手段または交通経 路, 列車, 便などの間での選択問題を扱えばよいことと なるが,このとき実験計画上, 交通手段の起終点, 運貢, 座席獲得可能性などのサービス特性など時間的要素を除 く他の条件が同一となっている必要があるため, 調査対 象例の摘出が実際上難しい. そこで本研究では, 通勤者 の駅へのアクセス行動を，列車発車時刻に対する利用者 の駅への到着予定時刻決定問題としてとらえ，対象とす ることとした。この場合，いつ駅へ到着したらよいかと いう到着時刻の予定の仕方によって, 所要時間は変化す るのに対してその他の条件（たとえば，運顀など）は一 定と考えることができる.

いま，駅までの距離が $l$ 通勤者のアクセス行動を考 える. この利用者の駅への到着予定時刻を $T_{A S C}$ とし, 利用者はアクセス所要時間を $t_{n s c}$ と想定して, 自宅の 出発時刻 $T_{s}$ を決定しており，また実際のアクセス所要 時間 $t_{n}$ により駅への到着時刻 $T_{A}$ が定まるものとする と,

$$
\begin{aligned}
& T_{s}=T_{A s c}-t_{n s c} \\
& T_{A}=T_{s}+t_{n} \cdots .
\end{aligned}
$$

となる.ここで, 所要時間 $t_{n}$ は, 種々の要因により確 率的に変動するため, その確率密度関数 (以後, PDF と記す）をアクセス距離 $l$ の条件付で, $\phi_{t n}\left(t_{n} \mid l\right)$ とする と, 所要時間の期待值 $t_{n E}$ は,

$$
t_{n E}=\int_{0}^{\infty} t_{n} \cdot \phi_{t n}\left(t_{n} \mid l\right) d t_{n}
$$

により, アクセス距離 $l$ 関数として得られるが, 想定 された所要時間 $t_{n s c}$ がこの期待值 $t_{n E}$ により定められる ものとすると, 式 (1),（2）より 


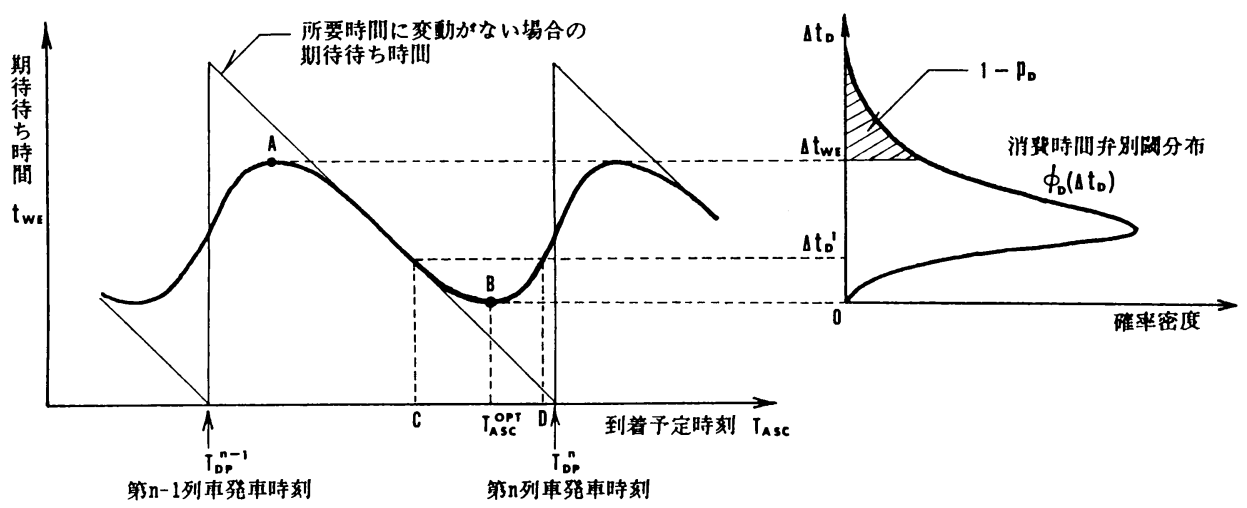

図一1 期待待ち時間と消霓時間弁別闘分布

$T_{A}=T_{A S C}-t_{n E}+t_{n}$

となるから, 到着予定時刻 $T_{A s c}$, アクセス距離 $l$ の条 件付で, 到着時刻 $T_{A}$ の PDF は,

$$
\psi_{T A}\left(T_{A} \mid T_{A s c}, l\right)=\phi_{t n}\left(T_{A}-T_{A s c}+t_{n E} \mid l\right)
$$

と表わすことができる.

さてここで，ある利用者が第 $n$ 列車の発車時刻と第 $n-1$ 列車の発車時刻の間の $T_{A s C}$ に到着予定時刻を定め たときの待ち時間の期待值 $t_{\text {WE }}$ は, 所要時間の変動によ り第 $n$ 列車前後の列車に乗車する場合も考慮すると, $T_{D P}^{i}$ を第 $i$ 列車の発車時刻, $N$ を $\psi_{T A}\left(T_{D P}^{n \pm N} \mid T_{A S C}, l\right) \doteqdot 0$ となる有限の非負の整数とすると,

$$
t_{W E}=\sum_{i=n-N}^{n+N} \int_{T_{D P}^{L-1}}^{T_{D P}^{i}}\left(T_{D P}^{i}-T_{A}\right) \cdot \psi_{T A}\left(T_{A} \mid T_{A S c}, l\right) d T_{A} \cdots
$$

と算出される. 列車間隔 $t$ ，が一定である場合には，い ずれの列車間を $T_{A s C}$ の変域としたときにも $t_{W E}$ は, 同 一の関数となることから, 以後複数の列車間隔のうちの 任意の 1 列車間隔を考えることとする ${ }^{\ddagger 11}$. 図一1 は, こ の待ち時間の期待値 $t_{W E}$ を到着予定時刻 $T_{A S C}$ に対して 図示したもので, $\mathrm{A}$ 点では, $t_{W E}$ が最大, $\mathrm{B}$ 点では最小 となっている.この 2 点での期待待ち時間の差を期待待 与時間差 $\Delta t_{W E}$ とおく.ここで, 利用者の駅へのアクセ ス行動を駅への到着予定時刻の決定行動としてとらえる と, 図一1において利用者は, 駅での待ち時間を不必要 に長くとる理由はないから, 到着予定時刻としては, 期 待待ち時間 $t_{\text {WE }}$ が最小となる時刻 $T_{A S C}^{o p t}$ を選択するもの と考えられる.

しかしながら, 利用者によっては, この時間差を意味 のある差異と認識しないこともあると考えられる. 特に 列車運行間隔が短い場合やアクセス距離が長い場合に は, 期待待ち時間差 $\Delta t_{\text {wE }}$ が相対的に小さくなることか

注 1) また, 多数の利用者集団をとった場合, その目的地, 到着予定時刻が千差万別であることから, ラッシュ時間帯の限 られた時間範囲についてみれば複数の列車間隔それぞれの乗客 の到着時刻の確率分布はほぼ同等となる.
ら，その傾向は強まるものと考えられる．そこで，本研 究では, こうした時間差に対する利用者の認知限界とし て, 弁別閥の概念を導入することとする. ここで, 利用 者の消費時間の弁別閾を $\Delta t_{D}$ とし，これが個体差等に より, $\operatorname{PDF} \phi_{D}\left(\Delta t_{D}\right)$ に従って, 確率的に変動している ものとする. このPDF をここでは, 時間弁別闘分布と よぶ. 仮に, 弁別閥 $\Delta t_{D}$ が図一1 の右側に示すように分 布しているものとすると, $\Delta t_{D}$ が $\Delta t_{\text {WE }}$ よりも大きい利 用者は到着予定時刻を $T_{A S C}^{o p t}$ に定めることにより得られ る時間差 $\Delta t_{\text {wE }}$ を認めないこととなる．この集団をここ では，非弁別集団とよぶこととする．この集団の比率を $1-p_{D}$ と表わすと, これは図一 1 中の斜線部分に該当す る. $p_{D}$ は, $\Phi_{D}\left(\Delta t_{D}\right)$ を時間弁別閾の累積分布関数として, 次により求めることができる.

$$
p_{D}=\int_{0}^{\Delta t_{W E}} \phi_{D}\left(\Delta t_{D}\right) d \Delta t_{D}=\Phi_{D}\left(\Delta t_{W E}\right)
$$

この非弁別集団の場合には, 期待待ち時間の最小値を与 える到着予定時刻 $T_{A S C}^{o p t}$ は積極的な意味を失い, 利用者 は，列車運行間隔の中でランダムに予定時刻を選定する ものと考えられるが, ここでは多数のサンプルを扱うこ とにより, 非弁別集団における到着予定時刻の分布が列 車運行間隔の中で一様に分布するものとする．したがっ て,この集団の到着時刻の分布 $\psi_{T A}^{I D}\left(T_{A} \mid l\right)$ は,

$$
\psi_{T A}^{D D}\left(T_{A} \mid l\right)=1 / t_{1}
$$

と表わされる.これを非弁別型到着時刻分布とよぶこと とする.

次に時間弁別閥が $\Delta t_{W E}$ よりも小さいたとえば $\Delta t_{D}^{1}$ の 利用者の場合について考えると, 期待待ち時間の最小值 に対する差が $\Delta t_{D}^{1}$ 末満となる時刻の領域（図一1中, $\mathrm{CD}$ の間) で到着予定時刻を決定すると考えられる.こ のような利用者の集団を弁別集団とよぶこととする．こ れを時間弁別閥が $\Delta t_{W E}$ 未満の利用者についてまとめる と， $T_{A S C}^{o p t}$ をピークとする到着予定時刻の分布が得られ るが，ここでは以後の時間弁別閾推定上，簡略化のため 
到着予定時刻がそのモード $T_{A S C}^{o p t} に$ 集中するものとみな して解析を進める注2).ここで，集中確率は， $p_{D}$ (弁別率) となる. すると弁別集団の場合の利用者の駅への到着時 刻の分布 $\phi_{T A}^{D}\left(T_{A} \mid l\right)$ は, アクセス距離の条件付で式 ( 5 ) より,

$$
\psi_{T A}^{D}\left(T_{A} \mid l\right)=\phi_{t n}\left(T_{A}-T_{A S C}^{o p t}+t_{n E} \mid l\right) \text {. }
$$

となる。これを弁別型到着時刻分布とよぶ.

したがって利用者全体の到着時刻の分布 $\psi_{T A}^{T L}\left(T_{A} \mid l\right)$ は，（８），（9）の両者を弁別率 $p_{D}$ を重みとして加算 することにより以下のように求めることができる.

$\psi_{T A}^{T L}\left(T_{A} \mid l\right)=p_{D} \cdot \psi_{T A}^{D}\left(T_{A} \mid l\right)+\left(1-p_{D}\right) \cdot \psi_{T A}^{I D}\left(T_{A} \mid l\right) \cdots(10)$ ここで，アクセス距離 $l$ が PDF $\phi_{l}(l)$ により分布してい るものとすると, 最終的な到着時刻の分布 $\psi_{T A}^{T L}\left(T_{A}\right)$ は,

$$
\psi_{T A}^{T L}\left(T_{A}\right)=\int_{0}^{\infty} \phi_{T A}^{T L}\left(T_{A} \mid l\right) \cdot \phi_{l}(l) d l
$$

により表わされることとなる.

また，所要時間の $\mathrm{PDF} \phi_{t n}\left(t_{n} \mid l\right)$ は，アクセス速度 $v$ の $\mathrm{PDF}$ を $\phi_{v}(v)$ として

$$
\phi_{t n}\left(t_{n} \mid l\right)=\phi_{v}\left(l / t_{n}\right) \cdot\left|d v / d t_{n}\right|=\left(l / t_{n}^{2}\right) \cdot \phi_{v}\left(l / t_{n}\right)
$$

により算出することができる.

以上より，任意の駅において列車運行間隔，アクセス 距離の分布, アクセス速度の分布, 利用者集団の時間弁 別閾の分布が得られておれば，これらによって利用者の 駅への到着時刻分布を記述できることとなるが，逆に本 研究では, 利用者の駅への到着時刻の分布を観測するこ とによって，利用者集団の時間弁別闌の分布を推定する ことを試みる。なお，複数のアクセス手段を対象とする 場合にも，手段別に上記の演算を行い，アクセス距離に 応じた分担率を用いて重ね合わせることにより到着時刻 分布を得ることができる。

\section{4. 首都圏鉄道通勤駅における実測調查}

\section{（1）調査対象駅の選定}

本研究では鉄道利用通勤者の駅への到着時刻分布を把 握するため，首都圈の 18 駅を選定し駅において乗客の 到着時刻を実測するという方法で調查を行った。ここて 調査対象駅の選定に際しては，特に次の点に留意した。

(1) 駅への到着予定時刻を通勤者が自由に設定できる ようにアクセス手段は歩行あるいは自転車が主たるもの （約 $90 \%$ 以上）であること．したがって，他の鉄道路 線からの乗り換えやバス路線の接続などがない駅である こと.また駅への到着を妨げる長時間の踏切待ちなどが

注 2） 後述の実測調查筒所のうちの数か所についてこのよう な簡略化を行わずに厳密に取り扱って時間弁別闘分布を推定し たが, 得られた弁別闘分布のパラメーターは, 簡略化して求め

\begin{tabular}{|c|c|c|c|c|}
\hline 社名 - 楾名 & 駅 名 & 方向 & $\begin{array}{c}\text { 運行間隔 } \\
\text { (何) }\end{array}$ & $\begin{array}{l}\text { 調查月日 } \\
\text { (昭和60年) }\end{array}$ \\
\hline 国鉄根岸㚘 & 山手 & 上り & 5 & $10 / 29$ \\
\hline 国鉄武茂野楾 & 船椅法典 & 下り & $12 \sim 13$ & $10 / 22$ \\
\hline 国鉄五日市楾 & 東秋留 & 上り & $16 \sim 18$ & $10 / 30$ \\
\hline 都営三田缐 & 白山 & 上り & $4 \sim 6$ & $10 / 29$ \\
\hline 営団丸ノ内楾 & 東高円寺 & 上り & $4 \sim 6$ & $10 / 22$ \\
\hline 党団千代田楾 & 千䭾木 & 下ク & $2 \sim 3$ & $10 / 29$ \\
\hline 東急田圆都市楾 & すずかけ台 & 上り & $6 \sim 11$ & $9 / 25,10 / 2$ \\
\hline 東急池上楾 & 洗足池 & 上り & 3 & $9 / 25,10 / 2$ \\
\hline 京王・京王楾 & 武花野台 & 上り & 12 & $9 / 25,10 / 2$ \\
\hline 京王 - 京王楾 & 平山城趾公圄 & 上り & 12 & $9 / 25,10 / 2$ \\
\hline 京王- 京王楾 & 声花公園 & 上り & 4 & $9 / 25,10 / 2$ \\
\hline 京王·京王裸 & 布田 & 上り & 7 & $9 / 25,10 / 2$ \\
\hline 京王井の䫄楾 & 三鹰台 & 上保 & $4 \sim 5$ & $9 / 25,10 / 2$ \\
\hline 西武池裚楾 & 高麗 & 上り & 30 & $10 / 22$ \\
\hline 西武新宿楾 & 都立家政 & 上り & 7 & $10 / 22$ \\
\hline 西武新筞楾 & 南大塚 & 上り & 15 & $10 / 22$ \\
\hline 西武国分寺楾 & 䳡の台 & 上り & $7 \sim 9$ & $10 / 22$ \\
\hline 西武多摩川線 & 多餧墓地前 & 上り & 12 & $10 / 29$ \\
\hline
\end{tabular}
た場合と $15 \%$ 程度の差異しか認められなかった。
表一1 調査対象駅一筧表

ないこと.

(2) 各列車の交通サービス条件をそろえるため次の点 に注意した．まず第 1 に，列車運行上の問題として，通 勤時間帯の列車によって所要時間の差（たとえば快速列 車と緩行列車の種別分け) や行き先の違いなどがないこ と. 第 2 に, 朝のラッシュ時における列車運行間隔が均 一であること．第 3 に，到着時刻によって列車内の座席 獲得可能性が変化するような状況の駅でないこと（一般 には路線の終点の駅でないこと).

（3）駅へ到着する利用者の通勤方向が特定できる駅で あること.このため，相対式ホームの駅が望ましい. そ うでない場合には着目する方向以外の乗客の割合がきわ めて小さいこと.

以上の(1)〜 (3)の観点から，首都圏の多数の通勤駅を昭 和 55 年度大都市交通センサスのデー夕解析および実地 踏查により検討し，表一1に掲げる 18 駅を調查対象に 選定した

\section{（2）調査の概要}

各駅では, 駅ホーム上で次の $2 つ$ 事項について実測 調査を実施した。

(1) 通勤者の駅ホームへの到着時刻測定

(2) 対象亡する方向の列車の閉扉時刻測定

次に多数の列車の発車時刻の間で測定された到着時刻 分布を発車時刻をそろえて重ね合わせた。図一2には, 実測された利用者の到着時刻分布の例を示した。なお， 2 日間にわたって測定を行った 7 駅については到着時刻 分布が測定日によって変化しないとみなせるかどうかを 情報量規準 AIC を用いて検定したが, 各駅とも調査両 日の分布は同一であると判定され，駅への到着時刻分布 が安定したものであることが明らかとなった。 


\section{5. 解析方法および結果}

\section{（1） アクセス長分布の推定}

本研究ではアクセス長 $l$ のPF : $\phi_{l}(l)$ の推定を APPENDIXに述べるような手順で行った。得られた $\phi_{l}(l)$ の例を図一3に示す.

\section{（2）所要時間分布の推定}

駅へのアクセス手段としての歩行および自転車の速度 は，いずれも対数正規分布に従うことが明らかにされて おり ${ }^{7), 8)}$, そのPDF は,

$$
\phi_{v}(v)=\frac{1}{\sqrt{2 \pi} \sigma v} \cdot \exp \left(-(\ln v-\mu)^{2} / 2 \sigma^{2}\right)
$$
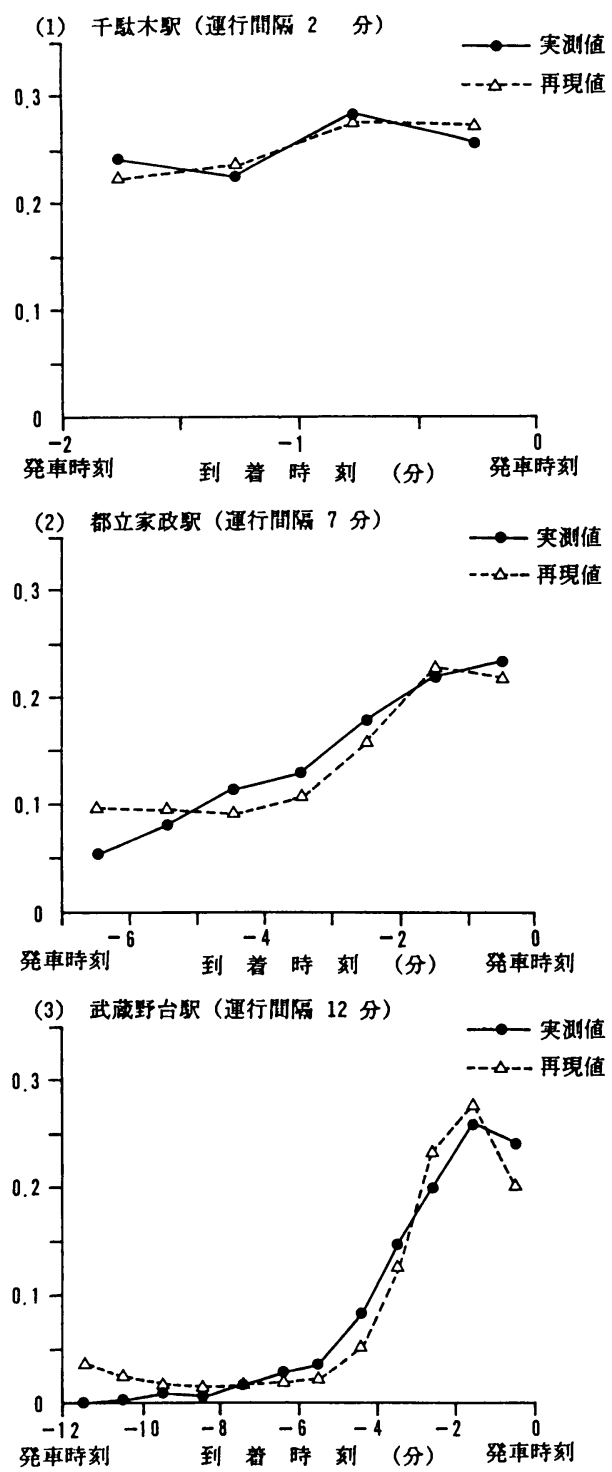

图一2 到益時刻分布

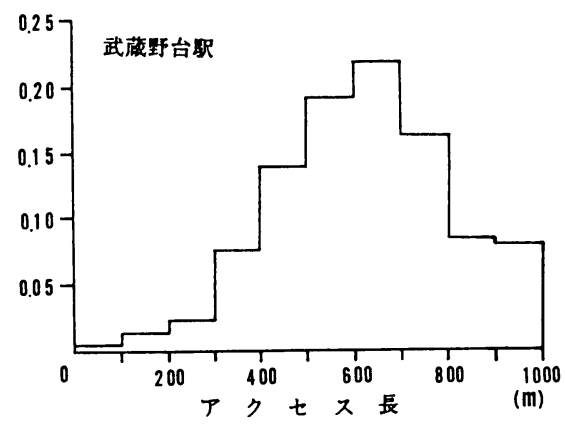

図一3 アクセス長分布の推定結果（例）

$$
\begin{aligned}
\text { ここに, } v: \text { アクセス速度 }(\mathrm{m} / \mathrm{s}) \\
\mu=0.328 \text { (歩行) } 1.406 \text { (自転車) } \\
\sigma=0.162 \text { (歩行), } 0.192 \text { (自転車) }
\end{aligned}
$$

と求められている. 本研究ではアクセス速度として上記 の分布を用いることにする.これより, 式 (12) からア クセス長が 1 のときの所要時間の確率分布が求められ る.

\section{（3）消賈時間弁別闘分布の推定}

a) 各ケース ${ }^{\text {i(3) }}$ の平均弁別率の推定

まず，時間弁別闉分布の形状を把握するため，以下の 予備的解析を行った.

式 (10), 式 (11) より利用者全体の到着時刻分布は, 以下のように導かれる.

$$
\begin{aligned}
\psi_{T A}^{T L}\left(T_{A}\right)= & \int_{0}^{\infty}\left\{p_{D} \cdot \psi_{T A}^{D}\left(T_{A} \mid l\right)\right. \\
& \left.+\left(1-p_{D}\right) \cdot \psi_{T A}^{I D}\left(T_{A} \mid l\right)\right\} \cdot \phi_{l}(l) d l
\end{aligned}
$$

ここで， $p_{D}$ は式 $(7)$ により求められるが，期待待 ち時間差 $\Delta t_{\text {WE }}$ はアクセス長 $l$ にって変化するので,

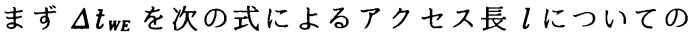
$\Delta t_{W E}$ の平均値 $\overline{\Delta t_{W E}}$ （平均期待待ち時間差）により代表 させる.

$$
\overline{\Delta t_{w E}}=\int_{0}^{\infty} \Delta t_{w E} \cdot \phi_{l}(l) d l \text {. }
$$

さらに, $\overline{\Delta t_{w E}}$ に対応する弁別率 (平均弁別率) を $\overline{p_{D}}$ と すると,

$$
\overline{p_{D}}=\int_{0}^{\overline{\Delta t_{W E}}} \phi_{D}\left(\Delta t_{D}\right) d \Delta t_{D}=\Phi_{D}\left(\overline{\Delta t_{W E}}\right)
$$

と表わすことができるが，式（14）を $\overline{p_{D}}$ を用いて次の ように近似する。

$$
\begin{aligned}
\psi_{T A}^{T L}\left(T_{A}\right) \doteqdot & \overline{p_{D}} \cdot \int_{0}^{\infty} \psi_{T_{A}}^{D}\left(T_{A} \mid l\right) \cdot \phi_{l}(l) d l \\
& +\left(1-\overline{p_{D}}\right) \cdot \int_{0}^{\infty} \psi_{T_{A}}^{I D}\left(T_{A} \mid l\right) \cdot \phi_{l}(l) d l
\end{aligned}
$$

ここで，各ケースについて式（17）から推定される利 用者の到着時刻分布 $\psi_{T A}^{T L}\left(T_{A}\right)$ が，実測された到着時刻分

注 3）同一の駅であっても時間帯によって列車運行間隔が異 なる場合には別のケースとした. 
布 $\psi_{T A}^{*} \cdot\left(T_{A}\right)$ に最も近似するように平均弁別率 $\overline{p_{D}}$ をそれ ぞれ求める. 具体的には列車運行間隔の中で時刻を複数 の代表座標点（30 秒～ 60 秒間隔）に区分し，離散化さ れた到着時刻分布の実測値と推定値の残差平方和を最小 とするようにすれば各ケースそれぞれについて平均弁別 率 $\overline{p_{D}}$ を推定することができる.さらに推定された平均 弁別率 $\overline{p_{D}}$ を用いて式 (17) より到着時刻分布を再現す ると図一2中の破線のようになる．表一2には，こうし て各駅について求められた平均期待待ち時間差と平均弁 別率，実測分布と再現分布の適合性を情報量規準 AIC により判定した結果を示す．表中，AIC (0) は再現分 布と実測分布が適合するとみなしたときの AIC 值, AIC (1) は適合しないとみなしたときの AIC 值である. これによれば一部に問題がないわけではないがほとんど のケースについて, AIC (0) の方が小さく適合すると みなしてよいことがわかる蝶．また図一2をみると閉扉 時刻の直前・直後において実測到着分布と再現到着分布 の適合度がよくないのは，演算の仮定上はアクセス速度 の分布はいつの時点でも同一であるとしているのに対し て，実測では閉扉直前に駆け込み乗車する乗客が多くみ られるためである. 以上より判断して各ケースとも推定 された到着時刻分布は実測分布とおおむね合致し，推定 された平均弁別率が妥当であることが明らかとなった。

b）時間弁別闘分布形状の推定

\section{表一2 各ケースの平均期待待ち時間差・平均弁別來}

\begin{tabular}{|c|c|c|c|c|c|c|}
\hline \multirow[t]{2}{*}{ 駅名 } & \multirow{2}{*}{ 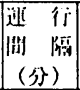 } & \multirow{2}{*}{ 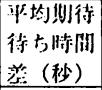 } & \multirow{2}{*}{ 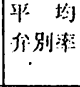 } & \multirow{2}{*}{$\begin{array}{l}\text { 我客数 } \\
\text { (人) }\end{array}$} & \multicolumn{2}{|c|}{ 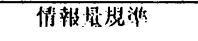 } \\
\hline & & & & & $\operatorname{AIC}(0)$ & $\operatorname{AIC}(1)$ \\
\hline 下殹木 & 2.5 & 21.5 & 0.273 & 758 & 4206.6 & $<4208.2$ \\
\hline & 3 & 34.6 & .154 & 643 & 3569.4 & 3572.0 \\
\hline 是池 & 3 & 23.8 & .481 & 889 & 4909.8 & 4912.0 \\
\hline 花公囬 & 4 & 66.4 & 0.215 & 1995 & 14234.7 & $<142$ \\
\hline 114 & 4 & 41.7 & 0.218 & 874 & 6262.8 & 8.7 \\
\hline 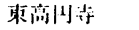 & 4 & 48.0 & 0.150 & 1664 & 11901.6 & 3.2 \\
\hline 滥台 & 4.5 & 63.9 & 0.589 & 4712 & 25287.8 & 6.3 \\
\hline 山拿 & 5 & 69.9 & 0.160 & 1358 & 8732.2 & $<8735.0$ \\
\hline 山 & 5 & 75.9 & 0.441 & 285 & 1822.7 & 1824.2 \\
\hline ケゲかけ台 & 6 & 92.5 & 0.894 & 318 & 2176.1 & 2184.4 \\
\hline 白山 & 6 & 117.0 & 0.330 & 219 & 1562.7 & 1571.4 \\
\hline 東高阿寺 & 6 & 7.2 & 0.434 & 606 & 4234.8 & 4236.7 \\
\hline 布且 & 7 & 183.7 & 0.703 & 319 & 2252.7 & 2254.5 \\
\hline 歺多かか什吉 & 7 & 133.2 & 0.822 & 582 & 4171.5 & 4177.5 \\
\hline 都立家政 & 7 & 7.0 & 0.440 & 627 & .3 & 4681.7 \\
\hline 盟の台 & 7.5 & 6.2 & 0.870 & 491 & & 4.8 \\
\hline 燃の台 & 9 & 8.9 & 0.910 & 475 & 8.4 & 0.5 \\
\hline すを゙がけ台 & 10.5 & 299.5 & 0.959 & 725 & 5333.8 & $<\quad 5337.6$ \\
\hline 武茂野台 & 12 & 415.1 & 0.809 & 1512 & 11768.1 & $>11767.6$ \\
\hline 欢山城淑公四 & 12 & 4.7 & 0.930 & 538 & .3891 .2 & $<\quad 3892.6$ \\
\hline 多曆整地解 & 12 & 444.4 & 0.781 & 1633 & 13313.9 & $<13237.2$ \\
\hline 船槅法典 & 12.5 & 424.6 & 0.691 & 1063 & 9205.6 & $>9202.2$ \\
\hline 大塚 & 15 & 563.8 & 0.762 & 647 & 5738.1 & 5753.9 \\
\hline 火留 & 16 & 601.5 & 0.855 & 515 & 4605.3 & 4609.8 \\
\hline 來秋留 & 18 & 712.2 & 0.797 & 208 & 1992.2 & 2021.5 \\
\hline 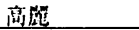 & 30 & 12.92 .1 & 0.955 & 845 & 7558.9 & $\leq 7564.3$ \\
\hline
\end{tabular}

注 4） AIC 值の差が 1 2 程度以上ならば, 有意の差とされ ている12).
次に各ケースについて推定された平均期待待ち時間差 と平均弁別率から弁別閾分布 $\phi_{D}\left(\Delta t_{D}\right)$ の形状を推定する こととする. 式 ( 7 ) より平均弁別率は, 平均期待待ち 時間差に対応した弁別闘分布の下側確率であることか ら，両者を対数正規確率紙に図示した結果，図一4に示 すようにばらつきは少なくないが相関係数も 0.75 と比 較的高く，弁別閥分布がおおむね対数正規分布に従う之 考えるのが妥当であることが明らかとなった．このこと は, 計量心理学における Fechner の法則をはじめとし て, 刺激の感覚量は物理量の対数に比例していることが 多いことや ${ }^{9)}$ ，時間弁別閥の定義域との斉合性を考えて も妥当なことといえる.

c) 時間弁別闘分布のパラメーター推定

以上の検討結果から各駅各ケースについて，時間弁別 閥が次に示す同一の対数正規分布,

$$
\phi_{D}\left(\Delta t_{D}\right)=\frac{1}{\sqrt{2 \pi} \sigma_{t D} \Delta t_{D}} \cdot \exp \left(-\left(\ln \Delta t_{D}-\mu_{t D}\right)^{2} / 2 \sigma_{t D}^{2}\right)
$$

に従うものとして, そのパラメーター $\mu_{t D}, \sigma_{t D}$ を推定す ることとする. ここで, 各解析対象ケースを添字 $j$, 各 ケースの測定対象乗客数を $n(j),(j=1, \cdots, m)$ とする.

(1) 桧消時間別

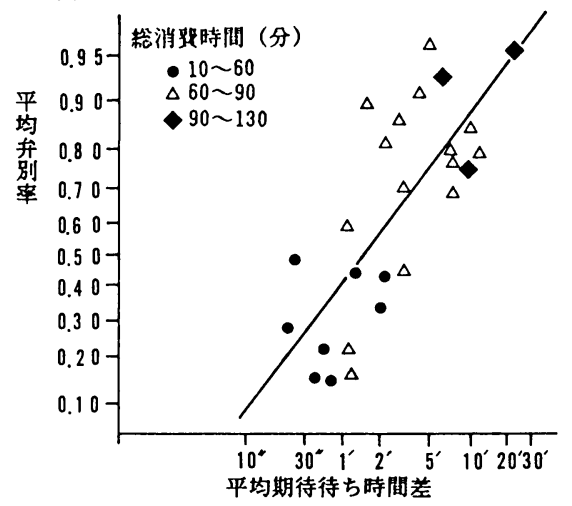

（2）リンク消費時間別

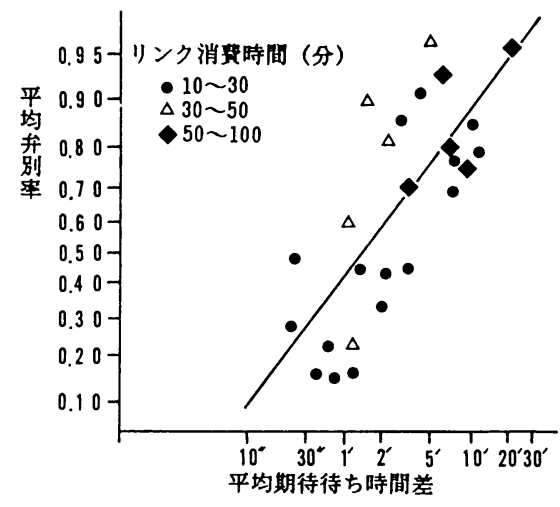

図一４消费時問弁別閶の分布形状の推定 
式（7)〜（11）により弁別閾分布を仮定して得られる第 $j$ ケースの到着時刻分布を $\psi_{T A}^{T L J}\left(T_{A}\right)$, 実測分布を $\psi_{T A}^{* j}\left(T_{A}\right)$ とする. すると全体での残差平方和 $S\left(\mu_{t D}, \sigma_{t D}\right)$ は,

$$
S\left(\mu_{t D}, \sigma_{t D}\right)=\sum_{j=1}^{m} n(j) \cdot \int\left(\psi_{T A}^{T L J}\left(T_{A}\right)-\psi_{T A}^{*}\left(T_{A}\right)\right)^{2} d T_{A}
$$

となるがこれを最小とするように弁別闘分布のパラメー ター $\mu_{t D}, \sigma_{t D}$ を決定してやればよい，この場合両者は， 数値計算により求めねばならないが, 本研究では両パラ メーターの初期值を図一4の結果より設定し, $S\left(\mu_{t D}\right.$, $\left.\sigma_{t D}\right)$ を逐次改善することにより求めた。このように撖密 に推定した場合と a), b) により簡略化して推定した場 合とでは結果的にみると，パラメーターには，10\% 程 度の差異がみられたのみであった．また，そのときの乗 客到着分布の適合度を情報量規準 AIC により検定した ところ，25 ケース中 22 ケースで再現分布が実測分布に 適合するという結果が得られた.この結果, パラメーター は $\Delta t_{D}$ の単位を秒にとったとき，

$$
\begin{aligned}
& \mu_{t D}=4.33 \\
& \sigma_{t D}=1.71
\end{aligned}
$$

となる.このとき消費時間弁別闘 $\Delta t_{D}$ の平均值は 5 分 24 秒で, 主な弁別率に対応する時間差を挙げると 11 分 14 秒で弁別率 $90 \%$ ，4 分で $75 \% ， 1$ 分 16 秒で $50 \%$ と なっており，文献 4）の意識調査で得られている閥値 2.3 分は, 本研究の結果からすると弁別率約 $61 \%$ に相 当し，大局的にみれば同程度の值となっている.

\section{6. 考察}

本研究で提案した消費時間に対する利用者の弁別閥お よびその分布という概念を用いて，利用者が消費時間を 最小化するように行動するという基本的前提のもとに利 用者の到着予定時刻决定メカニズムをモデル化すること により駅への到着行動を統一的に説明することができ た.この結果推定された時間弁別闘分布は，おおむね対 数正規分布に従うことが明らかとなった. 各ケースにお ける弁別率の推定結果をみると，この分布のパラメ一 ターはある程度の幅をもつものとは考えられるが，各弁 別率に相当する時間差から考えるとおおむねうなずける 結果となった，ただし，表一1にみられるとおり，今回 調査の対象とした各駅では, 弁別率は $20 \%$ 以上となっ ているものがほとんどを占め，データがやや高い弁別率 に偏った傾向をみせているため弁別率の低い領域につい ては信頼性が低くなっている.

前述のとおり，近年全国各地で鉄道輸送の速度向上が 精力的に推進され，旅客の獲得が図られているわけであ るが，その具体的状況をみると，たとえば昭和 60 年 3 月および 61 年 3 月の国鉄時刻改正時には，種々の改良
投資により

(1) 信越本線 (上野一長野) 3 時間 08 分 $\rightarrow$ 2 時間 54 分 14 分短縮 (60 年 3 月)

(2) 中央東線 (八王子一松本) 2 時間 59 分 $\rightarrow$ 2 時間 51 分 8 分短縮 (61 年 3 月)

(3) 函館本線（函館一長万部） 1 時間 27 分 $\rightarrow$ 1 時間 25 分 2 分短縮 (61 年 3 月)

等の線区で速度向上施策が実施されている.このような 中長距離旅客に本研究で対象としたような通勤輸送の結 果を適用するのは必ずしも妥当ではないが，上記ケース について，短縮された時間差を実効的な差として認知す る利用者の比率 (すなわち弁別率) を試算すると, それ ぞれ(1) $92 \%$, (2) $86 \%$, (3)61\%となり, (1)や(2)のケース ではかなりの比率の利用者が時間差として認知し，施策 が旅客に対してインパクトを与え（競争状態にある場合 の分担率がどの程度変化するかは別の話ではあるが）分 担率が変化し得る可能性を示唆している．しかしながら (3)のケースでは利用者の認知率は低く, 短縮されたこと すら十分には認識されない状況で，実効的なインパクト となったかどうか疑問が残る．以上のように時間短縮を 図ることにより他の交通機関との競争関係を改善しよう とする場合には, 分担率変化の予測と併せて, その施策 が利用者に対して行動様式を変化させ得るだけの実効的 なインパクトとなるかどうかを検討することが是非とも 必要と考える.

また，現在地方中核都市を中心として列車ダイヤのフ リークェント化が進められているが，その当面の目途は 列車運行間隔 10 分程度とされている。この值は本研究 の成果から判断すると弁別率 $89 \%$ に相当しおおむね妥 当な目標であると考えられる．時間差の弁別は本研究で 定式化したように絶対的な時間差を問題とするのではな く, 発地から着地までの総消費時間や当該りンクの消費 時間に対する時間差の相対的な大小が寄与するという可 能性も十分考えられるため，ここでは調査対象とした各 解析対象ケースにおける利用者の通勤に要する総消費時 間と当該リンク消費時間（つまり，当該路線上の降車駅 までの消費時間)を昭和 55 年大都市交通センサスのデー 夕を解析することにより把握し，その平均値を 3 つの ンクに区分して，図一4上に示した，しかしながら，総 消費時間またはリンク消費時間の各ランク別に平均期待 待ち時間差と平均弁別率の関係をみた場合，両者の相互 関係が消費時間の大小により明確な系統的違いがあると は，本調査により得られたデータの範用では，積極的に はみなしにくい結果となった。このことは交通目的が通 勤に限定され消費時間を数 10 分 2 時間程度に限定さ れる状況下では必ずしも不自然な結果ではないと考えら れるが, 今後なお一層の検討が必要であろう 


\section{7. 結 論}

本研究では, 通勤者の交通行動における消費時間につ いて利用者それぞれに認知可能な閥値すなわち弁別閥が 存在し，これが集団の中では確率的に分布すると考え， この概念を用いて駅へのアクセス行動を定量的に表現 し，実測調查および解析によりこれを定量的に推定する 方法を提案した。さらに首都圏の 18 駅において実測調 査を行い，その適用性を検討するとともに弁別闘の分布 形を推定したものである．本研究で得られた主な結論は 次のとおりである.

（1）利用者が消費時間を最小化するように駅への到 着予定時刻を決定するという仮説を基礎とし，その最適 化行動の結果, 利得として得られるであろう時間差を認 知できるか否かに関して弁別閥の概念を取り入れること により，通勤者の駅への到着行動を説明することができ る.また逆に利用者の行動を観測することにより時間弁 別閥の分布を推定することができる.

（2）通勤者の消費時間弁別閾の分布は平均が 5 分 24 秒程度の対数正規分布で近似され，たとえば $90 \%$ の 利用者が認知できる時間差は約 12 分となる.

（3）通勤者の消費時間弁別閥は，通勤に要する総消 費時間等の大きさに影響を受けるとは今回の調査に関す る限り積極的には認めにくい結果となったが, 今後さら に検討が必要である.

今回の研究では首都圈の諸駅を対象として解析した が，今後さらに調査検討を進めることにより得られた結 果の妥当性を確認する必要がある．得られた弁別閥分布 の地域的移転性の検討のためにはさらに別の地域での確 認も必要であり，またアクセス行動のみならず，別途の 実験環境についても今後検討していかねばならないと考 えている。

\section{8. あとがき}

本研究をまとめるにあたっては，実測調查をご快諾頂 いた日本国有鉄道, 東京都交通局, 帝都高速度交通営団, 京王帝都電鉄, 西武鉄道, 東京急行電鉄の関係各位なら びに直接実測に当たった本学土木工学科交通研究室の関 係各位に負うところ大であり，ここに深く感謝の意を表 すものである。

\section{APPENDIX}

A. 町丁目別世帯数統計を用いたアクセス長（直線距 離）分布の推定法

本研究では各対象駅の利用者のアクセス長分布を求め る必要があるが，ここでは町丁目の形状を考慮しつつ町 丁目別世帯数統計を用いて簡便に推定する次の方法を
とった

通勤者数は世帯数に比例し，また世帯数は各町丁目内 で一様に分布していると仮定する．まず当該駅の駅勢圏 内文5)にある各町丁目の形状を图一5に示す 2 タイプのう ちのいずれかの四辺形とみなし， $L_{1}, L_{2}, L_{m}, h$ などの 諸元を求める. すると各町丁目についての駅からの直線 距離の分布は図一5の下図のように求められる。そこで これを市区町村の住民基本台帳による町丁目別の総世帯 数で重みをつけて重ね合わせて, 全体のアクセス長（直 線距離）の分布とするものである.

次に，本法の妥当性を検討するため，通勤者数が家屋

(1) タイブ 1

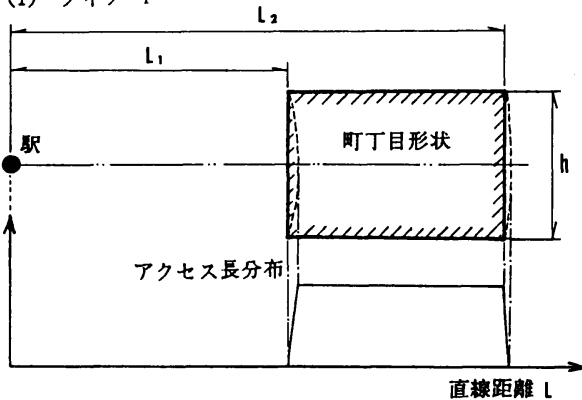

(2) タイプ II

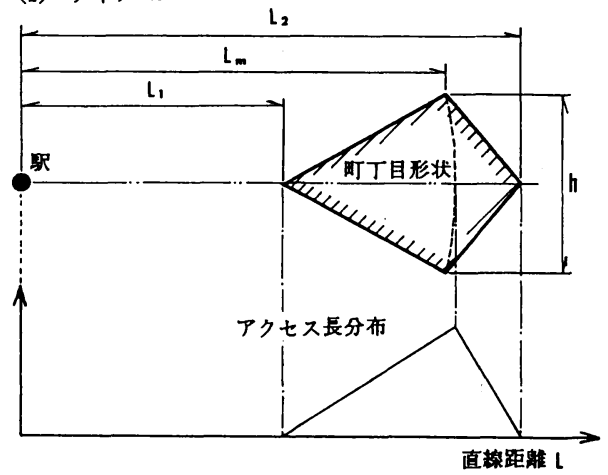

図一5 町丁目形状とアクセス長（直線）分布

\section{注 5）駅勢圈範囲の決定}

駅勢圈の範囲は, 徒歩の場合半径 $1 \mathrm{~km}$ 程度をとり, 隣接駅 間では両者の二等分線によるのが普通であるが ${ }^{10)}$, 本研究では アクセス手段が徒歩である比率が高い駅を対象としているため 基本的には，駅勢圈範囲はこれによることとした。ただし，自 転車等の利用率が無視できない数駅については次により駅勢圈 範囲を求めた。.まず，駅勢圈範囲を限定しない場合のアクセス 長分布を $\phi_{l}^{1}(l)$ ，このときの自転車等の利用分担率を $p_{b}(l)$ ，大都 市交通センサスの調査結果等から求められた当該駅の実際の自 転車利用率を $p_{b}^{*}$ として,

$$
p_{b}^{*}=\int_{0}^{l_{\max }} p_{b}(l) \cdot \phi_{l}^{l}(l) d l \text {. }
$$

となるような，アクセス距離最大値 $l_{\max }$ を求めれば，これが駅 勢圈範囲の推定値と考えることができる.なお，自転車利用分 担率の関数 $p_{b}(l)$ は，東京都の調布・三鷹地区を対象に実施され た調査結果 $\left.{ }^{11}\right)$ 一部を用い, 自転車の利用率にロジスティック 曲線をあてはめた以下の式を算出して利用した。 $p_{b}(l)=(1+60.0 \cdot \exp (-0.0034 \cdot l))^{-1}$ 
数に比例するものと仮定して, 詳細な住宅地図（ゼンリ ン社製)により圈内全家屋の駅までの直線距離を算出し, その分布をとったものと前述の簡便な方法によったもの とを比較することとした，図一6は，郊外駅と大都市内 駅それぞれの代表として東秋留と千駄木両駅について上 記の 2 種の方法によりアクセス長分布を求め, 比較した ものであるが，両駅の場合ともアクセス長分布がほぼ同 一の結果となっていることがわかる．この検討結果より 本法によってアクセス長分布を推定しても大きな間違い はないものと考え，本研究ではここに提案した方法を用 いて直線距離の分布を求めることとした。
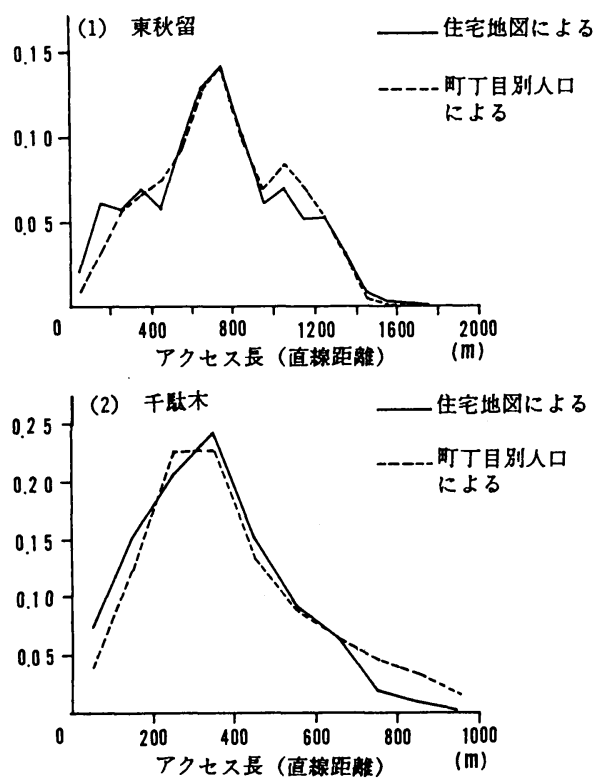

図一6 アクセス長 (直線) 推定結果の比較

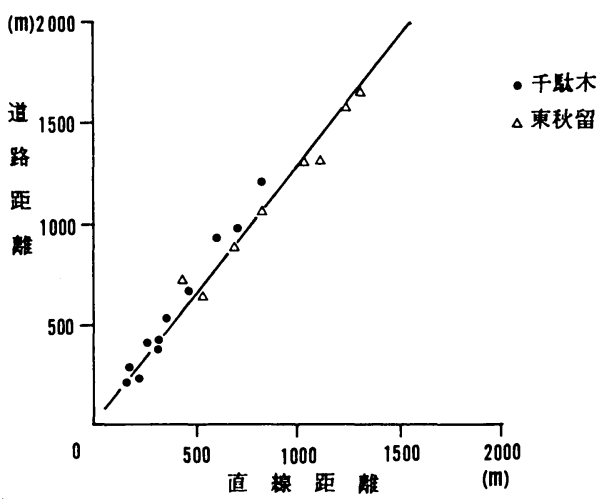

図一7直線距離と道路距離の関係

\section{B. 道路距離と直線距離の関係解析}

次に，アクセス長としては駅までの道路距離が必要で あるため, 以下の方法により直線距離と道路距離の相互 関係を把握した.

東秋留と千駄木の 2 駅について各町丁目の図心から駅 までの直線距離と最短経路と考えられる道路距離を地図 から求め, べき関数式を当てはめた結果, 次式が得られ た (図一7).

$$
L_{R}=1.89 \cdot L_{D}^{0.947} \text {. }
$$

ここに $L_{R}$ : 道路距離 $(\mathrm{m}), L_{D}$ : 直線距離 $(\mathrm{m})$ である. さらに, 得られた関係式の一般性を確認するため, 他の 駅 (すずかけ台, 三鷹台) について, 道路距離と直線距 離を求め, 上式の適用性を検討した結果，非常によく合 致することが確認された. そこで, 解析に用いるアクセ ス長は，A.で求められた直線距離の分布を上式により 道路距離に変換して用いることにした。

\section{参 考 文 献}

1) Keets, J.A. (島律一夫·石井 嚴訳)：計量心理学, pp. 13 27, 誠信書房, 1973.

2）相場 覚編：現代基礎心理学 2-知覚 I, pp. 193, pp. 231 232, 東京大学出版会, 1982 .

3）村上陽一郎編：時間と人間, pp. 23 39, 東京大学出版会, 1981.

4）谷 明良・宮武信春：通勤経路選好特性の計量化手法, 土木学会論文報告集, 第 267 号, pp. 83 87, 1977.

5）大山 正: 心理学研究法第 2 巻実験 I, pp. 1 5, pp. 16, 東京大学出版会, 1973.

6) 山形耕一：非集計行動モデルのための調査とデー夕作成, 第 15 回土木計画学講習会テキスト, pp. 75, 土木学会, 1984 .

7）松本嘉司 - 角 知憲 -田辺俊郎：一般化出発時刻に基つ く交通の実質消費時間の推定, 土木学会論文報告集, 第 337 号, pp. $180,1983$.

8）角 知憲 - 宮木康幸・村尾光弘・松本嘉司：任意の運行 間隔をもつ公共交通機関利用者の一般化出発時刻, 土木 学会論文集，第 347 号 $/$ IV -1, pp. 100， 1984.

9) 岡本栄一・藤田恵重：数理心理学の展開, pp. 11 12, 誠信書房, 1976.

10）八十島義之助・花岡利幸：交通計画，pp. 48，技報堂， 1971.

11）太田勝敏：非集計行動モデルの交通計画への適用に関す る研究 (II ), 東京大学工学部都市工学科, 1980 .

12）坂元・石黒・北川：情報量統計学, pp. 57 - 63, 情報科 学講座 A $\cdot 5 \cdot 4$, 共立出版, 1983 .

（1986.6.9 • 受付） 